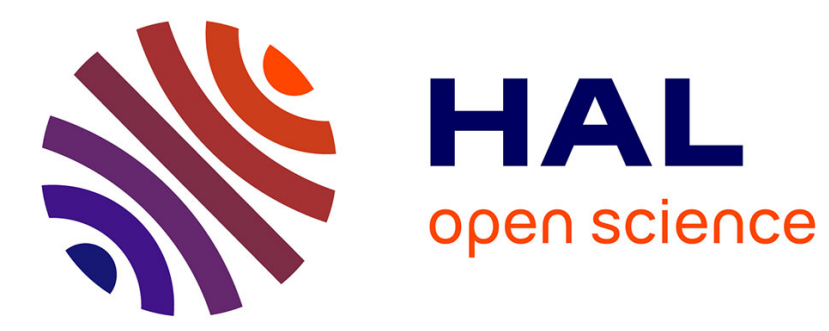

\title{
Small and Big Publishers in France: Is Literature a Rare Species?
}

\author{
Brigitte Ouvry-Vial
}

\section{To cite this version:}

Brigitte Ouvry-Vial. Small and Big Publishers in France: Is Literature a Rare Species?. Publishing Research Quarterly, 2003, 19 (1), pp.31-44. 10.1007/s12109-003-0021-7 . hal-02123105

\section{HAL Id: hal-02123105 \\ https://hal.science/hal-02123105}

Submitted on 11 May 2019

HAL is a multi-disciplinary open access archive for the deposit and dissemination of scientific research documents, whether they are published or not. The documents may come from teaching and research institutions in France or abroad, or from public or private research centers.
L'archive ouverte pluridisciplinaire HAL, est destinée au dépôt et à la diffusion de documents scientifiques de niveau recherche, publiés ou non, émanant des établissements d'enseignement et de recherche français ou étrangers, des laboratoires publics ou privés. 


\title{
Small and Big Publishers in France: Is Literature a Rare Species?
}

\author{
Brigitte Ouvry-Vial
}

\begin{abstract}
$\mathrm{A}$ $s$ suggested by the title, the general picture of literary publishing in France is not ideal, or idyllic. While the business in itself remains active, original and economically stable, the price of this stability is rather high. Literature pays the biggest part of the bill while commercial fiction, media-related documents, and best-selling authors are favored, along with developing sectors such as children trade books or practical books, encyclopedias, and dictionaries.

The tendency is not necessarily toward lower quality or hastily made books, since the children trade books sector, for example, has gradually imposed high standards of quality writing and of artistic and creative visuals. It is now admitted that children's writers are not secondary writers for nondemanding or weak readers. On the contrary, an observation of the production shows that the more it goes the more fiction writers skip freely from adult books to children's and vice versa, without lowering their standards. Also, more and more children book authors in France belong to a new type of creator: writing artists or writers with graphic gifts, that is to say, creators who express themselves equally by means of drawing or painting and writing. It would therefore be unfair and altogether wrong to describe French book production as decaying and the purpose of this communication is to bring nuances to this basic picture. But the general and exclusive rule of profit making which affects publishing in the United States has not left European publishing untouched.
\end{abstract}

\section{The American Reverse Perspective}

Among the features that characterize publishing in the United States, as recently denounced in André Schiffrin's book about the book business, some apply to French publishing as well. Schiffrin's provocative title "L'Édition sans éditeurs" (Publishing without Publishers) was inspired by French publisher Jerome Lindon, who died last April after having directed the famous Editions de Minuit for almost half a century. ${ }^{1}$

Of course, the meaning of this title is different whether it refers to the book business in the United States or in France, but the extreme situation which the U.S. book business has reached may be a foreshadowing of what could happen in Europe if we are not more careful. 


\section{Basic Facts Affecting Literary Publishing in the United States}

An estimated 85 percent of American publishing rests in the hands of four or five conglomerates that therefore control the public access to books, and the access of books to public opinion. It is an ideological control not by a political group but by private groups with private interests. This phenomenon is international and the direct consequence on books visible in publishers' catalogs. Economic profit rules the intellectual landscape and publishing decisions are made by financial and administrative boards with little background or interest in book publishing itself. Social sciences, translations, new authors, critical essays are all considered risktaking books: which means that they do not generate enough benefit, and the companies cannot afford to take risks. They want 15 percent benefit plus 10 percent growth factor a year, which generally speaking is an impossible goal to meet. The only way to meet these targets is to produce huge print outs of a book, to enforce sales by what Schiffrin calls "bribery bookstore," that is, to pay to have books on display, to concede large discounts for large display, to buy advertisement and newspaper articles to promote commercial books.

It is easy to deduce from this broad picture that literature is kicked out of the scene: sales remain well under 20,000 copies; losses on a non-profit making book are balanced by sales on a more commercial one; yet, in the new industrial conditions that rule publishing, this policy is not accepted anymore. Stocks sold to libraries are reduced. Literature is then taken care of by a hundred small non-profit presses devoted to publishing poetry, translations, and non-fiction on a more or less benevolent basis. In fact, even university presses are now becoming profit makers to meet new constraints and use every possible means to do so, including owning the copyright to professors' lectures.

\section{Is There a French Exception?}

Let us leave here this brief description of what can be called an intellectual disaster. Its main purpose herein is to provide a comparative background to emphasize what several publishers or observers call the "European exception," or more precisely, the French exception. A comparative background or a warning since concentration, which has allowed American publishing to reach this state of affairs, is also a reality in Europe and France. It is all the more true, in that the conglomerates which own 40 percent of American publishing are European -such as Reid Elsevier and Bertelsman-: thus, European publishing houses have been the first targets of these groups.

So taking for granted that the general policy within these groups is the same whether in France or in the United States, let us turn to the impact of the editorial concentration policy in France.

\section{Warning Signs of Cultural Decay}

Concentration is not a new phenomenon in French publishing, although it has accelerated in recent years. The French editorial landscape is reconfiguring itself 
around two multinational groups and three middle-size groups, the first two representing 65 percent of the total national income of publishing and almost all the educational publishing. Of course, there is a social effect and side to this concentration, but what we are presently more interested in is the cultural cost. As in the United States, high profit targeted is not possibly within reach for cultural products like books. This leads to an increase and an intensification of production, which affects its quality: indexes in encyclopedias are being updated by software rather than human thinking; tight budgets for scientific books do not allow for someone to help the author for second reading or rewriting; same thing for translations published without having been corrected; young authors or researchers are often asked to pay for the edition and publication of their books.

Recently, Lothar Baier, a renowned German writer, emphasized the courage of readers who keep buying books which publishers, although prestigious, did not take the time to edit. And he provides a striking memo of all the mistakes, orthographically, historical, geographical, found in the last laureate of the Goncourt prize, which sold a hundred thousand copies.

\section{Main Features of French Publishing}

Let us not comment upon commercial productions by publishers who publish documents and best-sellers while deliberately avoiding quality literary fiction. Rather, let us point out what remains significantly different, and how these differences serve literature. First of all, there is still in France a handful of rather big and influential publishing houses that remain independent and retain the traditional image or family heritage of their founders, whether or not present managers are members of this family. It is true for Gallimard, Flammarion, Albin Michel, still run by family members, and for Nathan, although the family no longer runs it. The maintenance of this image, prestige, and quality is among the current constraints of the present managers along with the financial growth of the firms; literature is not ruled out, but the purpose is on the contrary to keep high literary profiles and to back it by more best-selling products although it does not mean purely commercial products. For example, children's book collections by Gallimard are widely applauded and entirely remarkable, Le Seuil social science tradition is backed by a decent and sometimes excellent fiction production....

Second, and it is certainly a French specificity, the identity of the publishing houses are recognizable, in terms of types of books, authors, intellectual assets, public targeted. Third, and most importantly of all, there is a receptive climate for new publishers, small publishers and the competition remains possible, although unequal between small and big publishers. As long as small publishers commit to keeping a low industrial and economic profile, that is to say:

- Restrict to moderate or small printing quantity,

- Restrict to small projects with small budgets to keep prices low (e.g., a 100-page book for $10 €$ rather than 300 pages for $30 €$ ), and

- Restrict to limited public and count on bookshops rather than media to reach this public. 
This being a given, the cohabitation between big and small is possible and literature is the winner of the deal. This what we would like to concentrate on now.

\section{Small and Big Publishers in France and the Politics of Literature}

The French book industry presents a very specific landscape: dozens of small publishers hardly survive alongside a few prosperous big publishing houses. Despite enormous discrepancies in size, fame, and finances, the situation is gradually evolving into not so much a double standard system as to an unbalanced, unstated, but effective joint venture.

Let us start with some broad figures about the French publishing landscape: There are 300 to 500 registered publishing houses, the variation in number depending on the criteria (viability, number of titles per year, status) used to include or exclude small structures, and on the instability of the small structures themselves. From the mid-seventies to the mid-eighties, a period of time called "the spring of publishers," about 100 new publishing houses appeared each year. But of the 700 that started with real commercial activity on the national market in that period of time, only 57 percent were still active by the end of the eighties. And only half of these were publishing at least six titles a year, the minimum considered ensuring a mere survival of the enterprise.

Currently, the 300 to 500 existing publishing houses have a regular production and a global output of $\$ 2.5$ billion for a production of about 340 million copies. A large imbalance has resulted in eleven publishing houses contributing up to 55 percent of the global national result and 196 publishing houses contributing only 4 percent of the global result and 1 percent remains for an indeterminate number of microscopic or timely editorial ventures. To be more specific, eleven big publishing houses publish 73 percent of the school manuals and 86 percent of dictionaries and encyclopedias, fifty-one publishing houses publish over 200 books (fiction and non-fiction) each year with a majority of 82 percent reprints, and eighty-four publishing houses publish between one and nine titles a year. There is a reverse proportion of new releases and reprints between small and big publishing houses and in small publishers the ratio is $2: 1$, with twice as many new releases.

The general tendency across-the-board is an increase in the number of titles produced, a decrease in the amount of copies printed out and sold, an emphasis on children's books, and a regression of dictionaries and encyclopedias.

\section{Choice or Double Bind?}

Of course, all this has to do with two different strategies, industrial for big publishing houses and scale economy for small publishing houses. Two different logics prevail, marketing for the big ones, creation for small ones. Which does not necessarily exclude creativity within some sectors or departments of big publishing houses.

Each logic enlightens the general pattern which repeats itself in large publishing houses- dependence within the group, predominance of commercial authority and 
decision above editorial concern, short-term politics and objectives, pressure for more titles, pressure for internationalization and global book market, and a reduction of the editor's role and range of action to the minimum especially in terms of work with the authors. There is also a reverse repetitive pattern common to small publishers, which is independence, lack of diffusion and distribution network, an insufficiently visible catalog, low promotional budget (and therefore a reduced access to bookshops), a reduced shelf life of books in bookshops, and a tendency for authors to leave for bigger structures. One common feature is also that the publishers, who founded the enterprise and usually run it by themselves or with minimal help, actually do not make a living from publishing. They have occupations which more or less, rather less than more!, support the publishing business. These activities are not extraneous to literature or publishing itself: a great majority of small publishers work as academics -teachers, professors-, quite a lot of them as free-lance publishers, or packagers, or editors for other and bigger publishing houses, and quite a lot of them also combine various activities such as teaching, writing, translating, editing, and publishing.

The understanding of his or her role by the publisher-editor is another important criterion to distinguish big and small publishers: editors in big publishing houses tend to be more and more project directors; they have budget assignments but have little to do with the authors themselves or with the texts submitted. Publishers in small publishing houses often cumulate all tasks and act as publishers, graphic designers, and editors, including supervising the printing and coordinating the media promotion of the book. The financial constraint is dictated by their limited means only, but it often happens that out of passion and enthusiasm and since they invest their own money, they ignore the financial aspects and publish at any cost.

\section{A Two-Level Market}

There is also a geographic difference between big and small publishers: a majority of small publishers have settled down outside Paris, scattered in various regions although they do not necessarily publish regional literature. In a country which despite recent efforts remains heavily centralized, this aspect is important to describe the specific situation of big or small publishers within French publishing: on one side, Paris remains a major place of concentration of the literary and publishing life. Almost all big publishers are located in the city because this is where the readers are: a 1990 poll established that 33 percent of Parisians were heavy readers compared to the national average of only 20 percent. Eighty-five percent of the books published in France are edited in Paris and 95 percent of the national book trade comes from Parisian publishers. All structures of book diffusion and distribution compounds are also located not far from Paris and the attempt to create provincial centers has not proven very successful. On the contrary, books are mostly printed in other regions or abroad but this does not affect the centralization itself. 
So one can speak of a two-level market with on one side big publishers, big diffusion and distribution structures, major bookshops around the country, permanent and casual access to the means of promotion, to the media; and on the other side a secondary or sidemarket with small publishers, small and local diffusion, or self-diffusion, with only incidental connections to national media. Yet there are numerous exceptions to this pattern, and many serious and active booksellers nationwide do follow the production of small publishers and actually sell it on a regular basis.

However, small and big publishers coexist on two different scales, two different territories, and rarely interfere. Co-editions or co-publishing is not feasible between big and small publishers because their respective economical and practical conceptions of the book industry have little in common: big publishers are even sometimes suspicious about the high-quality/low costs achieved by small publishers; small publishers consider with great attention books by foreign writers, try to publish trade books at reasonable retail prices but in fine editions with fantasy and originality: for example, multiple ink colors in the same book, rich-fibered paper, vellum covers, facsimile, uncut pages or full printing page folded in four in an out-of-print appearance, handmade binding, old-fashioned typographic print, limited series, and so on.

\section{Readers and Writers' Literary Concern}

Despite the enormous difference in size and means, the battle is not necessarily lost for small publishers. To the contrary, the specific situation of literature within the French book trade, the desire of big publishers to retain part of the intellectual guidance, and the changes introduced or foreseen by electronic publishing devices, lead to a reconfiguration of some sectors of publishing wherein small publishers have a part to play.

The literary market in itself has suffered great changes in the last decades and on this specific ground big and small publishers are fighting an equivalent battle. The reduction of literary readership affects the number of copies issued-with a maximum of 2,000 copies for the first and often only print run-, the price of books, the hardship to attract the interest of journalists and get reviews. While radio broadcasting remains a major supporter for small publishers it reaches only a discrete public, and there are fewer and fewer major television shows interested in promoting real literature or in looking at cultural products not meant for a broader audience.

The development of electronic publishing and of multimedia may very well draw a line between new cultural products requiring big budgets, or specific and innovative conceptions and devices, and "traditional" books on paper. Putting aside all sorts of books which still need to be accessible on paper (e.g., manuals, workbooks, fiction), the specific area of literature induces publishers to a new challenge: the public of literature is confidential but demanding. The quality of the books published in this area has to be unquestionable in terms of choice, editing, printing, and so on. In view of this, the differences in proportion between big and small publishers do not necessarily mean the complete domination of the literary book 
trade by big ones, and small publishers may offer an answer to the expectations of both writers and readers as regards the continuing status of literature and the continuing tradition of quality on the making of books.

The quality of author/publisher relationships and the quality of editorial work on the books themselves is not improving in big publishers: many writers say they receive little attention; their books are not really read and discussed and amended; and because they have to fit in a collection, their uniqueness is not brought out by a distinctive conception in terms of cover, binding, or format.

The opposite still makes a difference in favor of small publishers. The risk-taking, the discovery and launching of new authors, the careful time spent on manuscripts, proofreading, the dedication to the shape and formal aspect itself of the book which is not only a reflection on the esthetics of the book but also a contribution to its meaning and a way to convey it to the reader, all this is more and more attractive to writers and readers looking and longing for "real publishers."

\section{The Publishers' Answer}

This is now a deliberate and well understood asset for small publishers who are not trying to compete with big ones, but on the contrary emphasize the originality, the aesthetic quality of their books, the inventiveness in terms of book binding, choice of paper, the intellectual touch of the publisher-editor in the paratext, the personal involvement in the promotion of the book, the practice of limited series that keeps them off massive displays in bookshops, as their way of asserting their specificity, of being visible, of attracting the amateurs of literature whose expectations are often disappointed by big publishers, that is to say people who appreciate the devotion to books perceived in small publishers and are interested to follow its development, and even to support the venture.

The development of small book fairs in the regions and the growing popularity of the "Marché de la Poésie" (Poetry Market), which takes place each year around the end of June in Paris in a square on the Left Bank (Place St. Sulpice), is a proof. It is obvious that visitors look forward to meeting with writers and publishers directly and to finding "rare species" in terms of contemporary books. In those circumstances, they disregard bigger publishers and well-known products.

There is a gradual conception of the "paper book" as an artistic product or a handicraft, of publishing as an act of interpretation that encourages small publishers in their concerns. This strong feeling is the basis of the solidarity within the community of small publishers: there are almost no joint ventures, because of everyone's limited means and the spontaneous, dedicated modus operandi; but nobody competes with one another and the community of understanding is the basis for an ongoing free exchange of advice, suggestions, and practical information on fonts, techniques, prices, and addresses.

Some big publishers like Gallimard, like Albin Michel with the collection "Ipomée," Flammarion, have also understood the need for atypical, non-standardized books complying with traditional criteria for typography, binding, and printing. They allow small sections or departments to develop original projects in order to keep in 
touch with this specific public. This explains why the present landscape of literary publishing in France shows a peculiar share taking or partaking of responsibilities that we will now enumerate.

\section{Literary Publishing Seen as a Joint Venture}

There is a partaking of "genres": novels and essays are massively published by big publishers; foreign literature and poetry by small publishers or by a few remote, yet notorious sections of big ones like Poésie Gallimard with the biggest poetry collection in France or like Poesie Flammarion with only six titles a year. Poetry is a choice.

A partaking of authors: notorious or best-selling authors for big publishers; new authors, forgotten and foreign authors for small publishers. In the catalog of $10 / 18$, a well known yet small publisher states, "One has to be mad to publish foreign writers, unknown in France, in pocket books. Let's be mad."

It also appears to be a law, or a given, that small publishers discover and launch new writers whom big publishers "take over" or buy afterwards. After their book meets success, authors frequently prefer the means of big publishers in terms of advances on royalties and of promotional investments. At the same time, if small publishers complain about the loss of their authors and the sheer ingratitude, they often admit that "keeping," coaching, and promoting a successful author can be very demanding and far less interesting than the discovery and the making of a new one.

A partaking of texts: by crossing points one and two, you get a third pattern. Big publishers retain the rights of publishing major novels or books by well-known writers but usually neglect the "leftovers" or secondary texts. It is common that a major writer will be published for two different types of book simultaneously by a big and a small publisher. A newcomer in literary publishing, Autrement, notorious for its sociological collective essays, developed in 1993 a collection of small texts, short stories, and side works by such big writers as Dostoyevski, Joseph Conrad, and even Plutarque, and recently met huge success with a translation of Kressman Taylor's Address Unknown (Inconnu à cette adresse), first published in 1939.

Same thing happens for contemporary writers. For example, François Cheng's essays are being published by Gallimard but for his poetry works, the author remains faithful to a microscopic publishing house, "Encre Marine," run by a professor of philosophy who edits, types, and binds the books himself and creates a specific format such as a tryptical book with three foldable pages for a trilingual version (French, English, and Japanese) of Cheng's poetry. Recently, the same small publisher has been approached by Gallimard with whom he "shares" Jacques Garelli, for a book gathering poetry and small philosophical essays. Gallimard did not have the flexibility, the collection, or the know-how to publish such a dual project and the author did not want his work split into two different volumes. In order not to lose the author, Gallimard decided to retire and extended the whole project to the small publisher.

Volker Braun, who won the Büchner preis for the year 2000 and is published by Surhkamp Verlag, had his first works in the seventies translated into French by 
medium-sized, communist-oriented publishing houses. His recent books, translated into French by one of his favorite translators, Alain Lance, a poet and director of the Maison des Ecrivains, were published by two different publishing houses: Actes Sud published Bodenloser Satz (La phrase sans fond) in 1993; but this text, very short, but dense and strong, made up of one continuous sentence, was misunderstood by both the editorial and commercial team of Actes Sud and presented in the usual longish format which caused the book to appear flat, unremarkable to the eyes of readers, and hence unsuccessful. L'Inventaire then published Braun's Vier Verzeugmacher (Les Quatre Outilleurs) equivalent in length, with more appropriate characteristics in terms of typesetting layout, format, thick and rich paper, and a front cover enriched with an illustration chosen and sent by the author himself. The book did not go unnoticed and the quality of print, the aesthetics of the final object have been since frequently praised. Despite the modest amount offered to buy the translation rights, the efforts made and the desire of Suhrkamp Verlag to ensure a continuity in the translation policy of the writer, now put L'Inventaire in a preferential position as regards future translations of his work. ${ }^{2}$

\section{The Politics of Literature}

A final aspect is the partaking of editorial policy or authority: rather than merely swallowing up small or medium-sized independent publishing houses, some big structures have decided to take advantage of the intellectual prestige and status of smaller structures. To cite several examples, Calman-Lévy publishes books under a double trademark in association with whoever offers a coedition in exchange of administrative, commercial, and technical logistics. Le Seuil usually invests in small "workshops" like L'Olivier, which remain independent in name and choices but whose originality and freedom is a beneficial contribution. Gallimard does the same with Le Promeneur, by example.

Actes Sud promotes itself through its own commercial team but to lower its costs, has taken charge of some other small independent publishing houses, like André Dimanche, Léméac, and L'Inventaire, whose image and production are sustaining. Actes Sud has also bought publishing structures such as Solin (mainly Russian literature) which it used to commercialize previously, as well as Sindbad (Persian and Arabic literature). In the two latter cases, the former publishers or literary directors remain in charge of the collections, as employees of Actes Sud, and the name of the former publishing house still appears as a "special brand" on the front cover. Yet the independence of Actes Sud is itself fragile and while it acts as a "big brother" to smaller structures, bigger ones are threatening it. Flammarion, who ensures its distribution, now holds 55 percent of its shares.

This leads to a final statement: there are two conditions for the coexistence of big and small publishers and the partaking in the French editorial politics of literature in France. First, small publishers must remain small, to avoid the inner conflicts passion versus financial constraints - and the threats to their viability and independence endured by medium-sized publishers. Second, it seems clearly understood that there is a moral attached to this story and that is, you must pay for what you 
get. The money making of big publishers has its counterpart in the relative dullness and vanity of their production. The passion and freedom of choice and action for small publishers has its counterpart in the non-profit making, the confidentiality of their endeavor. So that in the partaking of success, of reward, which is the last aspect of this implicit joint venture, big publishers take the money and small publishers the consideration.

\section{French Publishers and Their Cultural Mission}

Besides the joke, there is some truth in this last statement and being a publisher myself, I have often observed that the French publishing industry, I mean the people active as publishers, editors, booksellers, and so on, all consider their work to be a cultural and intellectual mission. Therefore, it is not rare to meet people working for good salaries in commercial publishing that regret the lack of intellectual freedom, the weakness of the "products" rather than books that they work on. While small publishers are generally passionate or "crazy" enough to keep working as they do, they benefit from a general broad appreciation of their work and contribution to literature and to the intellectual landscape of the country.

This, in my eyes, is based on a specific and strong feeling of belonging to a long tradition of book makers which goes back to the fifteenth century when the first printers after Gutenberg came from Germany with their techniques and settled in France, where it was possible to develop them as the means to transmit ideas of thinkers and doctors, religious or not. And while the current revolution induced by numeric and electronic publishing is considered based on a rupture with the order of speech, network, and properties on which traditional printing and publishing rely, I would like to underline that it does not cancel the standards of publishers or the reader's expectations. Nor does it affect in present publishers the sense of belonging to a long book history and a step-by-step construction and transmission of these orders. The connection between present small publishers and ancient printers while big publishers are radically turning to "merchandising," increases the consciousness of writer's and publisher's authorship within the survivors of literature and art publishing.

As a matter of fact, most publishers will tell you that technology does not change the problems or solve the problems that were not solved before. If numeric publishing is a step forwards in terms of price and time of printing, it does not however change the figure and the choice remains between hastily made books to meet information needs, and books that still require attention, time, adapted and specific editorial skills as well as aesthetic printing concepts to enhance and convey to the reader the quality and specificity of the text.

\section{Five Concepts from the Past}

One can extract from book history a list of techniques and values that founded their editorial practices and sense of craft and that we inherited from them. The goal is to answer a series of questions: What do we retain from these first printers 
who initiated a conception of the book that has prevailed ever since even if it is becoming today an endangered species? And what are we leaving for the new millennium? Are we transmitting the heritage that was left in our hands? Are we perpetuating the spirit, the aesthetic and artistic concerns, which granted the book its symbolic value? Among the numerous cases discussed in book history (and especially in a masterpiece by Antoine Claudin (Histoire de l'imprimerie au XV et XVI siècle, published for the Universal Exhibition of 1900), one can emphasize the case of a printer named Jean Trechsel, of German origin, who settled in Lyon around 1485 and became quickly known for the exceptional quality of his printing work, the originality and accuracy of the texts which were never copied from a previous edition as some printers used to do at that time, and where no mistakes could be found. His experience, his craft, one of his colleagues as well suggest a series of five traditional conceptions of the book that are still accurate for the literary publishers of today.

The first link and the only obvious one, is the character used to print Claudin's book which brought international renown to the "Caractères de l'Université," the achieved version for the Garamond that was named after its inventor, Claude Garamond, a French punch cutter of the fifteenth century. I will not get into the details of the creation, alterations, numerous copies and imitations in Europe and abroad, and final rediscovery of the character, but just point out that it is extraordinary that this character invented in the fifteenth century has become in traditional publishing as well as on-line (since computers do have this police) the incarnation of literature; it is the character most used in the twentieth century for literary prose, fiction, and essays. It is through the Garamond that we read literature most of the time, and before we read the text our approach is already oriented by the character with which it is associated.

Second, printers of the past conceived of the book as a whole to be invented and created from the beginning. Not as an empty frame or a ready-made tank to be filled with information. The book they were producing took its meaning not only from the text included but also from the formal object, which the text induced. The book altogether was meant as a genre in itself, where characters, formats, page setting, paper, publisher's signature, were equally taken in consideration and thought about in narrow connections the one with the others. And each new book meant a completely new thinking about the whole process of editing, printing, publishing, and reading.

Perhaps to counteract the concentration of the publishing world and its exclusive profit targets, small publishers today have developed a renewed carefulness, an innovating, playful, artistic conception of the book. The more they study typographic masters, and go back to the past to borrow the aspects and forms of new books: books made of wood, books in cases, in cylinders, printed in several colors, with Chinese bindings and folded pages. The more they adjust the formal aspect of the object book to its inner content and convey the beauty and specificity of the text through the beauty of the book.

Third, the first printers were convinced of the necessity and importance of their work and were moved by a sacred idea of books. Not only with respect to the fact that the first books were primarily Bibles or religious, but also because they were 
praising the value of science, literature, knowledge, were enthusiastic about transmitting it nationwide, and invested their skills and intellectual integrity and energy to do so with all the perfection desired, and by means adjusted to the contents as well as to the public identified for these books. What was true at this time where books were rare and unusual goods is once again true. It is the project of Schiffrin's non-profit, leftist New Press to publish authentic texts to answer real publishers' and real readers' literary and intellectual demands rather than to commercialize ready-made best-sellers or media-featured authors. It is our task and endeavor at l'Inventaire to publish foreign contemporary writers, often in bilingual versions to offer the amateurs a rich and diverse perception of Russian, Italian, person, German literature and to allow some of these writers in the case of Iranian or Afghan writers to reach an audience which would be impossible in their own country.

Fourth, to go on with the comparison between printers of the past and present small publishers and to exemplify the links and the continuing spirit between them and us, Trechsel was an exception in his time just as we small and real publishers are nowadays. He was an exception in the sense that from the books he published and the facts that can be retraced about the making of his books, it appears that he was actually and fully acting as a managing editor, a publisher, a printer, a bookseller, and was publicly praised by scholars and royalty alike for the importance and quality of his enterprise. Present small publishers work on their own, perform all tasks, devote most of their time to the achievement of the author's project, the correctness of the text, the accuracy and beauty of translations, the rigor of paratexts, as opposed to big firms where books are chosen on economic and mediatic criteria, and produced in chain work, with standardized schemes.

Trechsel was assisted by a literary director and copy editor - a rare fact at that time- that ensured the scientific value and rigor of the texts, and who contributed to Trechsel's reputation, and I only need to refer to the amount of grammatical or orthographical mistakes and "coquilles" left nowadays in trade books to show that such an intervention is not a luxury.

Fifth, as he was publishing a long three-volume set of medical science from Avicenne's Canon, he decided it would not be complete or critical enough without precious comments from Jacques Despars, who had been King Charles's doctor. Accordingly, Trechsel was the first to seek an author's permission to reprint comments that had been previously published. He then was also the first to ask for a royal privilege in order to respect literary ownership and to prevent random copies of the book by concurrent printers, and was granted this privilege. I am not developing these points, but anyone familiar with authors' rights, and with the many suits filed by authors and translators in order to retain their copyrights and intellectual property, will appreciate the necessity of such a moral and editorial rigor.

As to the privilege, it looks a precursor of the institutional help necessary today in order to pursue non-commercial, risky literary projects. Although we small publishers are trying our best to survive and to keep our practice free of any intervention, it is true to say along with Andre Schiffrin that literary fiction, poetry, humanities, and foreign literature all being part of the literary patrimony have become so hard to produce and to sell that we do need help and subventions to go on. 


\section{Literature as the Publisher's Legacy}

Trechsel himself was so thrilled by the perfection and success of his productions that he could not help advertising for it in various fanciful ways (Latin verses, rhymes addressed to the reader, prosopopia in which the book itself was praising the work of the printer) at the end of each book. A specific sense of his authority comes out of his practice. Like several of his colleagues, he considered himself an author, in the sense that he was actually giving life to a text and a book at the same time. The etymological origin of the word "editor" is, as you know, the Latin editus or edere "to give birth." And he was doing so not just technically but also with an additional artistic sense and sometimes called himself a "painter" as well. It was necessary to promote oneself in those times where bookshops did not exist and everything had to go slowly by word of mouth.

Today, small publishers find themselves in the same situation and for the same reason of asserting their identity and visibility, they return to the practice of publisher's address and signature on books. A practice which had been abandoned when books were sufficiently visible and at the same time when the market was not saturated. In the mid-century, a publisher like Jean Paulhan, a monument in his own right as a chief editor to the NRF and literary adviser to Gaston Gallimard, said that the ultimate and ideal publisher was the one who "was able to write without leaving a trace," to remain the powerful, but silent, invisible, implicit hand hidden behind the most famous and internationally renown writers of the century.

Today, the publisher- like ancient printers - cannot content himself with staying out of sight. He must stand beside his authors and support his books by means of a specific and identifiable trade mark or signature that both authors and readers recognize, appreciate, and feel connected to.

\section{Conclusion}

What then about the three rules or orders ${ }^{3}$ on the basis of which books began to be thought of and produced in the sixteenth century when the publisher had a claim on the authorship of the book? Do they still contribute to present each book as a unique arrangement, a specific object clearly related to a specific text and a specific person or author?

These orders that were maintained throughout centuries are suddenly on the verge of breaking or falling apart with the new regime of electronic, on-line publishing. I do not mean to appear rigidly traditionalist, but would like to emphasize that we should try to retain these arrangements and ties, one way or another, within the new order of numeric and on-line publishing where the text relies on the sole responsibility of the reader. The identity of the text and its authority are diluted; they disappear behind a continuum on screen where the text is a data bank which the reader can manipulate, reformat, alter, or expand as he or she wishes. It is so far impossible to trace the history of the text, -who wrote first, how did the writing evolve, what were the corrections made or sections added, where does the writer's intention stop, where does the editor's intervention start-, just because of the flat 
materiality of the screen associated with the interactive approach; the presence of the hypertext erases the linear approach.

Far from just resenting these opportunities, we should however point out that we will have to find ways of closing the text to protect the intellectual, literary, patrimonial, and moral rights of the author and to preserve the stability of his or her intended creation. Ultimately, when the inscription of the electronic text will be possible outside the computer, on a different support, the perception of the text, its status, will also be freed from its on-screen representation.

Second, the French or European exception described may be only a temporary one - authors, readers, publishers, booksellers, librarians, are aware that the situation is precarious, if not critical: in order to survive, literary publishers are bound to increase their production of titles. They increase the amount of printed copies above the expected market to maintain reasonable costs and keep up with low attractive retail prices; their margins are consequently reduced to almost nothing and this policy explains the decline and closure of many small publishing houses, even after a few reasonably successful titles.

Books have only short lives in bookstores; if not immediately enhanced by media promotion, a book will only survive a couple of months and is returned, at publisher's expense, to leave room for other novelties. Despite the "Prix unique du livre" (fixed retail price), big publishers have the means to discuss the way their books are being sustained in bookshops, whereas small do not. And mainstream books with a potentially big audience are likely to get more attention than young or foreign or unknown or confidential writers. Therefore the handful of publishers who still sticks to literature does so for the sake of it and at its own risks, while most publishers gradually turn to more profitable products. The worst of all this is that nobody really cares. As Jerome Lindon used to say: "Who would notice the absence of an unknown writer"?

\section{Notes}

1. Minuit is a very good literary publishing house, born during World War Two as an act of resistance against German occupation, and while this specific motivation disappeared when the war was over, the general spirit of involvement, literary involvement, remained and was enhanced under Lindon's influence.

2. A new edition of Die Unvollendete Geschichte und ihr Ende (L'Histoire inachevée et sa fin) was published in 2001 and a volume of Volker Braun's final short stories, Das Wirklichgewollte, is under translation.

3. Namely, the order of speeches or writings, the order of network, and the order of property. These three orders were developed by book historians like Roger Chartier or in different terms by Robert Darnton. 